\title{
Medically Assisted Insemination
}

\section{Andrology \& Gynaecology}

\begin{abstract}
Keywords: Procreation; Fertility; Infertility; Mother; Father
Abstract

Medically assisted procreation is a procedure that is carried out only when the former fertility treatment without success or hopeless, and in order to avoid transmission of serious hereditary diseases to the child with natural conception. Inefficiency or hopelessness infertility treatments determines the physician specialist in gynecology and obstetrics with a sub-specialization of human reproduction. The inevitability of transferring serious hereditary diseases to the child is determined by an expert in the field of human genetics who found a genetic hereditary disease or disease in one of the double or commonlaw partners.
\end{abstract}

\section{Introduction}

While a number of couples use different methods to limit their fertility and prevent new life, on the other hand a number of them and it is constantly growing - has only one desire: to acquire own child [1]. To accomplish this desire them no price is too high. Own desires, social pressures, as well as scientific-technical optimism and promises of reproductive medicine encourage them to constantly new attempts. The results do not remotely monitor all efforts, suffering and expenses incurred. Some of today's conventional medical methods are, morally speaking, problematic and contrary to human dignity.

The acceptance of the technical capabilities may at first glance mean relief and re-gaining control over the problem of infertility and their own bodies, and thus of life plans [1]. In reality, such a decision is an admission of its own helplessness; control over the body entrusted to experts. For the person it means subjecting extensive tests, the control of hormones, the daily blood tests, ultrasound scans, hospital stays for taking eggs or expressed words of one directly affected person, "... the constant hopes and fears and infinitely many disappointments". This regime shall be subject to the overall life of the person concerned, and often the spouse. So much investment of time to solve the problem of infertility is lack of time for other areas of life, profession and social relations, even among the married and cohabiting partners.

Since this problem is facing about $15 \%$ of the population of reproductive age, and to help its citizens, all modern states in their legal systems have laws dealing with medical treatment for infertility. In Croatia, the name of the law is the law on medically assisted insemination, and it regulates the conditions for exercising the right to medically assisted insemination and the rights, obligations and responsibilities of all participants in the procedures of medically assisted insemination [2]. In applying the procedures of medically assisted insemination protects the dignity and privacy of persons involved in the process of medically assisted insemination, as well as people who donate gametes or embryos. The procedures prescribed in this law shall be carried out in order to achieve conception, pregnancy and birth of a healthy child, in accordance with the requirements of modern medical science and experience, with particular regard to the protection of health of women, reduction of risks of treatment and well-being of offspring.

\section{The Manner and Purpose of Medically Assisted Reproduction}

We have recently been witness to rapid developments of science

\section{Siniša Franjić*}

Faculty of Medicine, Josip Juraj Strossmayer University of Osijek, Republic of Croatia, Europe

\section{*Address for Correspondence}

Dr. Siniša Franjić, Faculty of Medicine, Josip Juraj Strossmayer University of Osijek, Cara Hadrijana 10/E, 31000 Osijek, Republic of Croatia, Europe, Tel: +385-31-51-28-00; Fax: +385-31-51-28-33; E-mail: sinisa.franjic@gmail.com

Submission: 24 May, 2016

Accepted: 17 June, 2016

Published: 21 June, 2016

Copyright: (c) 2016 Franjić S, et al. This is an open access article distributed under the Creative Commons Attribution License, which permits unrestricted use, distribution, and reproduction in any medium, provided the original work is properly cited.

Reviewed \& Approved by: Dr. Ossama Elsaccar, Reproductive Endocrinology and Infertility, University of Vermont College of Medicine, USA

and scientific developments in numerous areas of human activities [3]. A day hardly passes by without us learning about a new invention that will either facilitate our life, or make it more difficult, at least for the traditionalists among us, depending on individual attitudes. The scientific fields that stand out in several ways in this regard definitely include biomedicine. Biomedicine has made an enormous progress lately, which was completely unimaginable even a few decades ago. We can only guess how far the new discoveries in this field will take us. Could we soon become immortal or at least get close to that goal? Will we soon be able to prolong and maintain the quality of our life with the aid of new vital organs, which will replace the ailing and degenerated ones and will be provided by our cloned duplicate or will be grown in a laboratory from the omnipotent stem cells? Has man already been successfully cloned, following the success in cloning Dolly the sheep?

Medically assisted insemination is carried out using modern scientifically proven biomedical advances that enable the connection of male and female gametes to achieve pregnancy and childbirth, in a manner different than intercourse.

The selection process of medically assisted insemination (natural cycle, mild stimulation of ovulation or default) decides spouse or common-law partner or wife, along with medical specialist in gynecology and obstetrics with a sub-specialization of human reproduction.

About appropriate methods of medically assisted insemination Croatian Society of Gynecologic Endocrinology and Human Reproduction Croatian Medical Association will draw up guidelines for the compulsory treatment of infertility.

\section{Members of the Right to Medically Assisted Insemination}

From law shows that the procedure of medical insemination applicable for spouses and common-law spouses [4]. The fact that 
unmarried couples are equal in this right to spouses arises from the constitutional meaning of married persons. The constitutional provisions on the legal regulation of common-law and special social protection of the family. Extramarital community is a new form of family and community on a variety of legal areas and in legal branches enjoys protection. Therefore, common-law couples as legal entities (individuals) and as a woman and a man does not suffer any discrimination and are equal in their right to insemination with spouses.

The right to medically assisted insemination are of legal age and legal capacity of women and men who are married or in commonlaw and that due to the age and general health condition capable of parenting a child. The right to medically assisted insemination has adult, legally capable woman who does not live in marriage, commonlaw or same-sex unions, whose previous fertility treatment proves unsuccessful or hopeless, and that is due to the age and general health condition capable of parenting a child. The right to medically assisted insemination and the person who has the decision on deprivation of legal capacity is not restricted to making statements concerning personal status. The right to medically assisted insemination at the expense of the Croatian Institute for Health Insurance has a wife normally until they reach 42 years of age. The doctor who performed the procedure medically assisted reproduction, for particularly justified for health reasons may allow the right to medically assisted insemination and a woman older than 42 years of age.

Infertility treatment procedure medically assisted reproduction at the expense of the Croatian Institute for Health Insurance includes:

1. Four attempts at intrauterine insemination (IUI)

2. Six attempts at in vitro insemination (IVF), with the obligation that the two attempts are in the natural cycle.

3. The right to medically assisted insemination has a wife with whom he established hopelessness of other forms of treatment.

4. Reproduction opportunities women establishes a physician specializing in gynecology and obstetrics with a subspecialization of human reproduction based on tests of ovarian reserve. Women older than 42 years or women whose ovarian reserve tests unfavorable, the doctor is obliged to draw attention to the poor results of treatment, the risks of treatment and pregnancy and risks to the child.

\section{The Existence of a Marriage or Common-Law}

Marriage or cohabitation must exist at the time of gametes or embryos in the woman's body. The existence of the spouses prove relevant public documents. The existence of a common-law community common-law couples prove the statement certified by a notary public.

Before starting the process of medically assisted insemination spouse or common-law partners are obliged to medical institution in which to carry out the process of medically assisted insemination deliver consent. In terms of the law on medically assisted insemination unmarried couples make women and men who do not live in a marriage, in other common-law or same-sex unions, and who meet the requirements for a valid marriage.

Who is the parent of a child born as a result of assisted reproduction? The basic approach of the law has always been that the woman who gives birth to a child is the mother and that the father is the genetic father of the child [5]. It is presumed that her husband or the man registered as the father on the birth certificate is the father. These presumptions can be rebutted by DNA tests. However, special rules apply in cases of assisted reproduction.

The factual and legal situation in terms of parenting is the same as after natural and medically assisted insemination if the latter is achieved by homologous insemination [6]. However, if the fertility can not use gametes coming from a person (double or common-law partners), which provides medical care, according to the procedure of heterologous insemination creates the condition for which the relevant additional medico-legal and family law rules. Assuming medico-legal regulations allow donation of reproductive cells of both sexes, in the case of application of donated seminal cells to fertilize the woman, the biological father of the child would not be the mother's husband, and whether they are used for insemination of donated eggs, the woman who gives birth to a child will not be the genetic mother, but gestational parent.

\section{Information on Medically Assisted Insemination}

The Constitution does not explicitly mention any right of privacy. In a line of decisions, however, going back perhaps as far as Union Pacific R. Co. v. Botsford, the Court has recognized that a right of personal privacy, or a guarantee of certain areas or zones of privacy, does exist under the Constitution [7]. In varying contexts, the Court or individual Justices have, indeed, found at least the roots of that right in the First Amendment; in the Fourth and Fifth Amendments; in the penumbras of the Bill of Rights; in the Ninth Amendment; or in the concept of liberty guaranteed by the first section of the Fourteenth Amendment.... Only personal rights that can be deemed "fundamental" or "implicit in the concept of ordered liberty" are included in this guarantee of personal privacy. . . . The right has some extension to activities relating to marriage; procreation; contraception; family relationships; and child rearing and education.

The spouse or common-law couples or women, are entitled to notice of the possible forms of natural family planning, the treatment options for infertility and other ways to achieve parenthood (For example, adoption), especially if they are both women and men infertile.

Prior to the implementation of procedures of medically assisted insemination doctor, master of biology or other licensed health care worker marital or non-marital companions and the woman is obliged to explain the details of the process, the prospects of success and the possible consequences and risks of procedures for woman, man and child.

\section{Legal and Psychological Counseling before Medically Assisted Insemination}

Before carrying out the procedures of homologous insemination marital or non-marital companions can provide psychological or psychotherapeutic counseling. 
Legal and psychological or psychotherapeutic counseling shall be carried out prior to the heterologous insemination.

Master of psychology or a psychiatrist is required to marriage or common-law spouses or women, aware of the possible psychological effects of the procedure medically assisted insemination. About conducted counseling master psychologist or a psychiatrist issued a written confirmation.

Master of law the health institution where the procedure is performed heterologous insemination is required to marriage or common-law spouses or wives of the legal meaning and effect of consent to a planned process of medically assisted insemination, family law effects arising from a particular medical procedure and in particular the child's right to know that is conceived medically assisted insemination and the right of a child to know who their biological parents are. About conducted counseling master rights issue written confirmation.

The health institution in which to conduct medically assisted insemination can alone ensure the implementation of legal and psychological counseling or psychotherapy, and if it can not, is obliged to refer the marriage or common-law spouses or wives, to another medical institution in which they are implemented, this consultation or in people authorized for psychological or psychotherapeutic counseling and with master rights for legal advice.

\section{Consent to Medically Assisted Insemination}

Methods of medically assisted insemination governed by the Law on medically assisted insemination can be carried out only if they are married, unmarried couples, and women, familiar with the details of the procedure of medically assisted insemination and advised accordingly and if you are in the process of giving free and informed consent in writing [8]. Certified consent is given for each procedure medically assisted insemination, in particular with regard to the type of procedure medically assisted procreation and the origin of gametes or embryos.

Double, unmarried couples individually or together, or woman, can withdraw consent and abandon the process of medically assisted insemination until sperm or eggs or embryos have been entered in the body of a woman. The process of medically assisted insemination suspend the declaration of withdrawal of consent of one or both partners, or common-law partner or wife. After the withdrawal of consent, sexual cells are destroyed, and the embryo is stored for the purpose of giving the user the right to medically assisted insemination. A statement on the withdrawal of consent health care institutions shall be recorded at the request of a woman or a man about to issue a written confirmation. Before entering the seminal cells, eggs or embryos in the body of a woman doctor is required to check whether the consent was withdrawn.

\section{The Right of Access to Information about Donors}

A person conceived and born with the help of medically assisted insemination bestowal sperm or donated egg or donated embryos, if the age of 18 has the right to inspect the register data of insemination and all information about their biological origins, including information about the identity of the donor sperm or the giver of the egg or embryo donor and the information on the identity of the person, which is kept in the National register of Medically assisted insemination of the ministry responsible for health.

Parents are obliged person conceived and born with the help of medically assisted insemination bestowal sperm or donated egg or donated embryos, no later than the age of 18 , know that was conceived with the help of medically assisted insemination.

Access to data on the donors of gametes or embryos will allow the legal guardian of the person or persons to the doctor if it is at his request, because of medical reasons justified and well-being of persons, previously approved by the National commission for medically assisted insemination. The right of access to the register and information on the person and the donors of gametes has court, a government body when necessary in connection with the application of this Law. Persons to inspect the register are required to file information born person and donors of gametes or embryos, and the available data from the register be kept secret in accordance with special regulations.

\section{Conclusion}

Medically assisted reproductive is a highly specialized branch of medicine which go around infertility, usually in cases where the cause of infertility can not be eliminated. Since the woman and man sexual cell sperm and the process of insemination the same as in nature, in using is the term medically assisted, rather than artificial insemination, because medicine only allows insemination occurs, but does not replace the process itself artificial insemination procedure. The problem of infertility is a major global problem because with him is facing about $15 \%$ of the population of reproductive age, and with wish to help its citizens, all modern states in their legal systems have laws dealing with medical treatment for infertility. In addition to consulting with a doctor, it is necessary, in accordance with national legislation in force, take a couple of very important steps before accession, medically assisted insemination. How does it work in practice and what that ultimately means for people who are faced with this problem, is described in this paper.

\section{References}

1. Aničić M (2007) Marital infertility and its options. BS 77: 181-216.

2. The law on medically assisted insemination NN (Narodne novine/National newspaper) - 86/2012.

3. Skubic VZ (2008) The issue of consent in bio-medically assisted reproduction procedures (the case of Evans V. The United Kingdom"). Zbornik Pravnog fakulteta u Zagrebu, Zagreb 58: 1141-1158.

4. Hrabar D (2010) Legal scope of medical insemination in Croatia. Zbornik Pravnog fakulteta u Zagrebu, Zagreb 60: 415-442.

5. Herring J (2011) Medical law (1 ${ }^{\text {st }}$ edn.), Oxford University Press, Oxford, UK.

6. Alinčić M (2006) Medically assisted procreation and Family law conflicts of interest. . Zbornik Pravnog fakulteta u Zagrebu, Zagreb 56: 883-910.

7. Kranz R (2002) Reproductive rights and technology. Library of congress cataloging-in-publication data, New York.

8. Gmajnić R, Franjić S (2016) Social and health legislative. Medicinski fakultet Sveučilišta Josipa Jurja Strossmayera u Osijeku, Osijek. 